DOI: https://doi.org/10.12797/Politeja.15.2018.53.07

\title{
Eugeniusz MIRONOWICZ
}

Uniwersytet w Białymstoku

ebma@interia.pl

\section{ROLA IRANU, IRAKU I SYRII W POLITYCE BIAŁORUSKIEJ}

ABSTRACT The role of Iran, Iraq and Syria in the policy of the Belarusian

Relations between Belarus and Iran, Iraq and Syria after 1998 took on the nature of political alliance. The factor connecting Belarus with these countries was their isolation by the West because of the policy of internal or foreign. Sanctions or restrictions imposed on these countries on the initiative or with the participation of the United States created an additional platform for Minsk agreements with Tehran, Baghdad and Damascus. Anti-Americanism four countries has become a common feature of their foreign policy and defense cooperation. Closeness of political relations was accompanied by a desire to establish a broad economic cooperation between the four countries. At the beginning of $21^{\text {st }}$ century it grew by leaps and bounds each year, the volume of trade between Belarus and Iran, Iraq and Syria. Level exchanges with Iran and Syria, however, quickly reached a level corresponding to the potential capabilities of the parties and far removed from the expectations of leaders. Any dealings with Iraq were interrupted as a result of the occupation of that country by the United States and the coalition.

Key words: Belarus, Iran, Iraq, Syria

Słowa kluczowe: Białoruś, Iran, Irak, Syria 


\section{POLITYCZNE I EKONOMICZNE UWARUNKOWANIA WSPÓŁPRACY}

Rozpad Związku Radzieckiego dał Białorusi niepodległość, lecz jednocześnie spowodował destabilizację gospodarki. Przemysł republiki funkcjonował wówczas w oparciu o surowce i energię pochodzące z Federacji Rosyjskiej. Ich zakup na wolnym rynku przyczyniał się do zadłużenia państwa i galopującej inflacji. Przemysł białoruski stracił także tradycyjne rynki zbytu, które znajdowały się w krajach postradzieckich. Inne republiki znajdowały się w podobnym lub jeszcze gorszym położeniu i nie miały środków na import towarów produkowanych na Białorusi.

W pierwszych latach niepodległości rząd białoruski, starając się zapobiec bankructwu państwa, próbował uzyskać kredyty i szukać rynków zbytu na Zachodzie, lecz nie znajdując zainteresowania drugiej strony, zdecydował się na powrót do strategicznego partnerstwa z Rosją - pomimo ustępstw politycznych, ograniczających suwerenność kraju. Pogrążona w tym czasie w kryzysie Rosja niewiele jednak mogła zaoferować. Dlatego rząd białoruski starał się równolegle szukać partnerów w Azji, przede wszystkim w Chinach, Japonii i Indiach. Gospodarcze efekty tych działań okazały się dość skromne ${ }^{1}$.

Pierwszy prezydent Białorusi Aleksander Łukaszenko kontynuował i umacniał azjatycki kierunek polityki zagranicznej państwa. W jego przypadku były to w dużej mierze działania wymuszone gwałtownym pogorszeniem relacji z Zachodem. Wybór autorytarnego modelu zarządzania państwem sprawił, że od 1996 r. Białoruś była stale obłożona sankcjami utrudniającymi rozwój i izolowana gospodarczo przez Stany Zjednoczone, kraje Unii Europejskiej i niektóre państwa postkomunistyczne Europy Środkowo-Wschodniej, aspirujące do członkostwa w strukturach euroatlantyckich. Sytuacja taka wymuszała poszukiwanie kontaktów z kolejnymi państwami Azji, w których spodziewano się znacznie łatwiej i bez konieczności wypełniania jakichkolwiek warunków politycznych uzyskać kredyty i rynki zbytu dla białoruskich towarów przemysłowych ${ }^{2}$.

Cechą wspólną partnerów azjatyckich był brak zastrzeżeń w kwestii białoruskiej demokracji i metod sprawowania władzy przez Łukaszenkę oraz najczęściej krytyczny lub zdystansowany stosunek do polityki amerykańskiej³ . W drugiej połowie lat 90. najbliższe relacje w Azji Białoruś nawiązała z Chinami, Irakiem, Iranem i Syrią. Przywódcy tych krajów bez oporów przyjmowali prezydenta Łukaszenkę lub byli goszczeni przez niego w Mińsku. Niektórzy, jak Saddam Husajn rządzący w Iraku lub Hafiz al-Asad pełniący władzę w Syrii, byli postrzegani na Zachodzie, zwłaszcza przez Amerykanów, w sposób podobny do Łukaszenki.

1 E. Mironowicz, Polityka zagraniczna Biatorusi 1990-2010, Białystok 2011, s. 34-52.

2 Kimай надасиь Беларусі крэдьт на адзін мільярд даляраў, [online] http://telegraf.by/2010/03/ktaj-nadasc--belarus-kredit-na-adzn-ml-jard-daljara.html, 25 XI 2015.

3 В. Мацемь, Отношения Республики Беларусь с государствами северо-восточной Азии, [online] http://www.library.by/portalus/modules/belarus/referat_readme.php?subaction=showfull\&i$\mathrm{d}=1182261885 \&$ archive $=\&$ start_from $=\&$ ucat $=4 \&, 28$ XII 2015. 
Jednobiegunowy świat w cieniu amerykańskiej potęgi, który ukształtował się po zimnej wojnie, był nie do zniesienia dla białoruskiego przywódcy deklarującego najwyższe uznanie dla nieistniejącego państwa radzieckiego, które jego zdaniem było jednym z filarów bardziej sprawiedliwego porządku światowego. Sojusz z krajami, które zajmowały krytyczne lub niechętne stanowisko wobec USA, był tego logiczną konsekwencją.

Dla Białorusi ważniejsze niż kredyty były nowe rynki zbytu dla produkcji przemysłowej. Przemysł białoruski był zbudowany w czasach radzieckich z myślą o produkcji na potrzeby ogromnego imperium i jego satelitów. W niepodległej Białorusi bez eksportu tracił rację bytu. Takim firmom, jak Mińska Fabryka Traktorów lub Mińska Fabryka Autobusów czy przedsiębiorstwom zbrojeniowym - Integrał, Peleng, Agat szansę na przetrwanie dawała jedynie sprzedaż produkcji za granicę. Pozostająca w stanie zapaści gospodarczej Rosja, która w latach 90. radykalnie zmniejszyła swoją armię oraz zaniechała zbrojeń, stanowiła mocno ograniczony rynek zbytu, biorąc pod uwagę możliwości wytwórcze białoruskiego przemysłu. Eksport na Zachód był mocno utrudniony nie tylko z powodu sankcji, lecz także niskiej konkurencyjności białoruskich produktów. Koniecznością stało się zatem poszukiwanie alternatywnych rynków zbytu oraz inwestorów zainteresowanych nabywaniem udziałów białoruskich przedsiębiorstw i ich modernizacją ${ }^{4}$.

Duże znaczenie w budowaniu kontaktów z krajami Azji miał handel bronią. Po rozpadzie ZSRR Białoruś była krajem pełnym magazynów broni przeznaczonej dla $\mathrm{Ar}$ mii Radzieckiej, której kraj nie potrzebował w tak ogromnych ilościach; potrzebował natomiast pieniędzy na zakup surowców. Starając się pozbyć niepotrzebnego uzbrojenia, w drugiej połowie lat 90 . Białoruś stała się jednym z większych jego dostawców do krajów, które niegdyś były zaopatrywane przez ZSRR, zwłaszcza tych położonych nad Zatoką Perską .

\section{STOSUNKI Z IRANEM}

Stosunki Białorusi z Iranem były w dużym stopniu determinowane przez czynniki polityczne. Napięte stosunki ze Stanami Zjednoczonymi oraz sankcje polityczne lub gospodarcze nakładane przez Zachód na Iran i Białoruś skłaniały rządy tych państw nie tylko do współpracy bilateralnej, lecz także do traktowania Rosji jako gwaranta bezpieczeństwa ${ }^{6}$.

Współpraca polityczna była logiczną konsekwencją położenia międzynarodowego obu krajów, stanowiła także czynnik sprzyjający kontaktom gospodarczym. Mimo zainteresowania rządów Białorusi i Iranu wymianą handlową poważną barierą w jej

С.Ф Свилас, Т.В. Евсейчык, Отношения Республики Белорусь со странами Арабского мира в 1996-2006 годах, Минск 2009, s. 18-19.

Tamże, s. 20.

6 B. Bojarczyk, Stosunki biatorusko-irańskie, [w:] Biatoruśw stosunkach międzynarodowych, red. I. Topolski, Lublin 2009, s. 255. 
rozwoju, tak jak w przypadku większości zaprzyjaźnionych krajów azjatyckich, było oddalenie geograficzne i wynikająca stąd konieczność korzystania z pośrednictwa terytorialnego, transportowego i logistycznego Rosji. Dawało to Federacji Rosyjskiej możliwość kontrolowania stosunków bilateralnych Białorusi nie tylko z Iranem, lecz także z większością państw azjatyckich.

Stosunki dyplomatyczne między Białorusią i Iranem zostały nawiązane w 1993 r., zaś placówki dyplomatyczne w randze ambasad w Mińsku i Teheranie otwarto w $1997 \mathrm{r}$. Świadczy to o tym, że przez kilka lat po uzyskaniu niepodległości Białoruś była w niewielkim stopniu zainteresowana regionem Zatoki Perskiej i Bliskiego Wschodu. Izolacja Białorusi przez Zachód sprawiła, że w Mińsku dostrzeżono Iran jako kraj z $80 \mathrm{mln}$ konsumentów i potencjalnie wielki rynek zbytu ${ }^{7}$. Nie bez znaczenia był konfrontacyjny charakter stosunków irańsko-amerykańskich, który z kolei zmuszał Teheran do poszukiwania sprzymierzeńców gotowych do możliwie szerokiej współpracy w warunkach sankcji gospodarczych nałożonych na Iran $^{8}$.

Współpraca Białorusi z Iranem rozpoczęła się zatem w wyniku złożonej sytuacji międzynarodowej obu państw. Iran był jednym z kilku krajów azjatyckich, które w 1998 r. odwiedził Aleksander Łukaszenko i gdzie wśród rozmówców spotkał się z podobnymi do swoich poglądami na temat większości problemów międzynarodowych. Podczas wizyty w Teheranie w marcu 1998 r. i rozmów z prezydentem Mohammadem Khatami obie strony podzielały opinie na temat bezpieczeństwa w Europie Środkowej oraz regionie Zatoki Perskiej'. W interesie Białorusi leżało, aby broni atomowej nie było na terenie krajów nowo przyjmowanych do NATO, zaś w przypadku Iranu problem stanowiła broń jądrowa w posiadaniu armii izraelskiej.

Prezydenci obu krajów we wspólnym oświadczeniu zgodnie deklarowali, że są zwolennikami zachowania suwerenności swoich krajów w stosunkach bilateralnych oraz relacjach wielostronnych $z$ innymi panstwami i zdecydowanie przeciwni narzucaniu przez niektóre kraje [w domyśle: USA, Wielka Brytania - E.M.] swoich zasad i rozwiazań prawnych innym panstwom ${ }^{10}$.

Według białoruskich politologów o bliskości stosunków białorusko-irańskich decydowały trzy czynniki. Najważniejszym był antyamerykanizm przywódców obu krajów, który determinował całość relacji międzypaństwowych. Dwa pozostałe wynikały z potrzeb obu krajów. Białorusi potrzebna była irańska ropa naftowa, zaś Iranowi białoruska broń oraz części zamienne do radzieckich samolotów i czołgów ${ }^{11}$. U schyłku XX w.

Ю.В. Коваленя, Нормативно-правовал база взаимодействия Беларуси и Ирана (1993-2014), [w:] Белорусь в современном мире. Материаль IX Международной научной конферэнции посвященной 93-летию образования Белорусского государственного университета, Минск 2014, s. 51.

8 А. Асгар Шахбаз, Внешнеэкономическое и политическое взаимодействие Республики Беларусь и Республики Иран в условиях глобализащии, „Иппокрена” 2015, vol. 1, nr 26, s. 54.

9 Сумеснал беларуска-іранскал залва, [w:] Знешнял палітька Беларусі. Зборнік дакументау i матэрызлаў (1996-2000), t. 8, Мінск 2008, s. 168.

10 Tamże.

11 Чаму Беларусь і Іран иягнущца адзін да аднаго?, оріnie Igora Lalkowa i Andreja Fiodorowa, [online] http://news.akavita.by/ru/belarus/248190.html, 28 XII 2015. 
położono jedynie podwaliny pod współpracę polityczną i gospodarczą, którą z ogromnym rozmachem kontynuowano w pierwszej dekadzie nowego stulecia.

Po przejęciu kontroli nad Irakiem przez Stany Zjednoczone i ich sojuszników Iran stał się głównym partnerem Białorusi w Azji Środkowej. Złe stosunki obu krajów z jedynym mocarstwem światowym, bardzo aktywnym w pobliżu ich granic - Stanami Zjednoczonymi - skłaniały do zacieśniania współpracy. Sankcje polityczne i gospodarcze nakładane przez Zachód na Białoruś i Iran tworzyły w obu krajach podobny obraz zagrożeń ze strony świata zewnętrznego. Jeszcze w trakcie wizyty Aleksandra Eukaszenki w Teheranie w marcu 1998 r. zawarto liczne porozumienia dotyczące współpracy politycznej, gospodarczej, wojskowej, kulturalnej i naukowej. Wymierne wyniki zawartych porozumień okazały się niewielkie, gdyż w Teheranie długo traktowano Białoruś jako drugorzędny kraj, pozostający w cieniu Rosji. Moskwa tymczasem starała się przestrzegać sankcji nałożonych na Iran przez ONZ. Dopiero silniejsza presja ze strony NATO wobec Iranu po 2003 r. skłoniła jego władze do poszukiwania poparcia wszystkich potencjalnych sojuszników, mających podobny stosunek do Zachodu ${ }^{12}$.

Impulsem do rozpoczęcia bardziej aktywnej współpracy Iranu z Białorusią była wizyta prezydenta Mohammada Khatami w Mińsku we wrześniu 2004 r. Rok później, gdy prezydentem Iranu został Mahmud Ahmadineżad posługujący się podobną do Aleksandra Łukaszenki retoryką antyamerykańską i antyzachodnią, Białoruś i Iran szybko zdecydowały się na wzmożenie współpracy we wszystkich dziedzinach. W listopadzie 2006 r. z wizytą w Teheranie przebywał prezydent Białorusi, zaś w maju 2007 r. Mińsk odwiedził M. Ahmadineżad. Prezydenci i tym razem składali wspólne deklaracje wyrażające sprzeciw wobec narzucaniu przez Zachód swojego systemu wartości krajom, które wybrały własną drogę rozwoju. Podpisano liczne kontrakty, które tworzyły solidne fundamenty współpracy gospodarczej i wojskowej ${ }^{13}$. Białoruską ofertą były produkty przemysłu zbrojeniowego, traktory i usługi budownictwa drogowego. Iran miał do zaoferowania ropę naftową, której potrzebowano w Mińsku, także jako argumentu w relacjach z Moskwą ${ }^{14}$.

Ton komunikatów Ministerstwa Spraw Zagranicznych (MSZ) Białorusi po wizycie Mahmuda Ahmadineżada pokazywał zbieżność poglądów obu prezydentów, ich wolę poszerzania współpracy, zaś podpisywane umowy i porozumienia między przedstawicielami centralnych banków i poszczególnych ministerstw tworzyły podstawy prawne pozwalające na wdrażanie składanych deklaracji w życie ${ }^{15}$. Problemem obu krajów był brak kapitału, który wszelkie kontrakty czynił jedynie rejestrem intencji ich przywódców.

12 А. Аукоянов, Иран: взгляд без предубеждения, [online] http://polit.ru/research/2008/03/16/iran. html, 2 V 2015.

13 B. Bojarczyk, Stosunki biatorusko-irańskie, s. 256-257.

14 Аукашэнка: незалежнасиь ад расійскай нафты і газу каштуе вельмі дорага, [online] http://telegraf. by/2010/09/lukashenka-nezalezhnasc--ad-rasjskaj-nafti-gazu-kashtue-vel-m-doraga.html, 2 V 2015.

15 Паведамленне МЗС Рэспублікі Беларусь аб візіще у Беларусь прэзідэнта Ірана, „Веснік Міністәрства замежных спраў” 2007, nr 2, s. 11-12. 
Największy kontrakt białorusko-irański podpisany we wrześniu 2007 r. przez państwową firmę Biełorusnieft i Irańską Narodową Kompanię Naftową dotyczył wydobycia i sprzedaży ropy z pól Joferieh położonych w pobliżu granicy z Irakiem. Wartość kontraktu przewyższała $500 \mathrm{mln}$ dolarów. Szacowano, że pole udostępnione geologom białoruskim jest bardzo bogate, pod ziemią miała zalegać ilość ropy równa 2,1 mld baryłek. Do końca 2020 r. Białoruś miała pozyskać z tego źródła dziewięć milionów ton ropy. Problem stanowiła jednak powierzchnia pola naftowego mocno naszpikowana minami pochodzącymi z czasów wojny iracko-irańskiej. Władze Iranu obiecały rozminować pole, lecz do 2008 r. nie podjęto żadnych działań w tym kierunku ${ }^{16}$. Drugą przeszkodą był brak środków w białoruskim budżecie na zbudowanie odpowiedniej infrastruktury. Ropa, zgodnie z podpisanym kontraktem, miała być wydobywana już w 2009 r., lecz informacja o rozpoczęciu eksploatacji złóż pojawiła się dopiero w lutym 2011 r. ${ }^{17}$ Oficjalne otwarcie pól naftowych Joferieh z udziałem prezydentów planowano w październiku 2010 r., lecz uroczystość taka nigdy się nie odbyła ${ }^{18}$. W sierpniu 2011 r. białoruska firma Biełorusnieft zrezygnowała z realizacji kontraktu. Oprócz braku odpowiednich rezerw na realizację inwestycji powodem rezygnacji były także sankcje amerykańskie nałożone na Biełorusnieft za współpracę wojskową Białorusi z Iranem, które sprawiły, że kontrakt stał się nieopłacalny ${ }^{19}$. W lutym 2013 r. ambasada irańska w Mińsku ogłosiła całkowite zamknięcie projektu wydobycia ropy realizowanego wspólnie z Białorusią ${ }^{20}$.

Drugi wielki kontrakt zawarty w 2006 r. dotyczył budowy przez irańsko-brytyjsko-białoruskie konsorcjum montażowni samochodów osobowych IKCO Samand na Białorusi. Irańczycy liczyli przede wszystkim na szybką realizację postanowień Euroazjatyckiej Unii Celnej i ominięcie w ten sposób opłat przy eksporcie samochodów na rynek rosyjski ${ }^{21}$. Planowano roczną sprzedaż 60 tys. sztuk pojazdów tej marki. Na Białorusi irańskie auta cieszyły się bardzo małym zainteresowaniem, zaś szanse ekspansji na rosyjskim rynku okazały się iluzoryczne $e^{22}$.

16 Беларусь-Иран: совместныце проекты на сумму $\$ 1,5$ млрд. или 1000 и одна сказка, 12 II 2009, [online] http://afn.by/news/i/113669, 21 V 2015.

17 Іран рэалізуе у Беларусі праекты на 1,5 млрд. далspаў, [online] http://telegraf.by/2011/02/ran-realzue-belarus-praekti-na-15-mlrd-daljara.html, 1 V 2015.

18 Татїе; Беларусь - Иран: многранность взаимодействия, [online] http://www.export.by/?act= news\&mode $=$ view\&id $=23759,8$ V 2015.

19 А. КАасковский, Аруг Махмуд не оправдал надежд Аукашенко, „Салідарнасц” 2013, 11 II, [online] http://www.gazetaby.com/cont/art.php?sn_nid=53634, 15 V 2016; К. Иванов, Как Беларусь собиралась торговать с Ираном на \$ 1 млрд и что из этого выцило, „СахіАарнасць” 2015, 17 II, [online] http://www.gazetaby.com/cont/print_rdn.php?sn_nid=90355, 15 V 2016.

20 Т. Коровенкова, Беларусь и Иран полностью закрыли проект по добыче нефти на Ажофеире, „Самідарнасць” 2013, 5 II, [online] http://www.gazetaby.com/cont/art.php?sn_nid=53423, 15 V 2016.

21 С. Богаан, Om Каракаса до Тегерана: белорускал дипломатия в Азии, Аатинской Америке и Африке, „Бемоуский ежегодник” 2009, s. 113.

22 К. Иванов, Как Беларусь собираласв... 
Znacznie większe znaczenie dla rozwoju obustronnych kontaktów Białorusi i Iranu miały małe kontrakty zawierane przez lokalne władze obu krajów. Dotyczyły one współpracy agrotechnicznej, budowy hoteli, infrastruktury drogowej ${ }^{23}$. Każde miasto obwodowe na Białorusi miało swojego partnera w Iranie ${ }^{24}$. Choć bilans wymiany handlowej w 2010 r. zbliżał się do $100 \mathrm{mln}$ dolarów i był pięciokrotnie większy niż w 2005 r., to wciąż daleko mu było do oczekiwań zawartych w oświadczeniach przywódców obu krajów ${ }^{25}$. Planowano bowiem zwiększyć wielkość wymiany handlowej do miliarda dolarów ${ }^{26}$. Szacunki te okazały się jednak zbyt optymistyczne. Wprawdzie w 2012 r. wartość wymiany handlowej przekroczyła 140 mln dolarów, lecz w 2015 r. była znów niewiele większa niż w 2010 r. ${ }^{27}$

Irański ekspert ekonomiczny Mohammad Reza Kamali stwierdził, że wymiana handlowa z Białorusią jest utrudniona ze względów strukturalnych. Zarówno Iran, jak Białoruś eksportują towary mało przetworzone, wyprodukowane przy niewielkim wkładzie pracy intelektualnej. Oba kraje importują natomiast produkty wysokich technologii, które służą do bezpośredniego wykorzystania i nie podlegają dalszej obróbce. Każda z tych gospodarek, aby mogła być konkurencyjna, wymagała inwestycji. Z punktu widzenia Iranu inwestycje na obszarze Białorusi byłyby ekonomicznie uzasadnione. Argumentem przemawiającym za inwestowaniem w tym kraju była Euroazjatycka Unia Celna oraz szybko i systematycznie rosnąca konsumpcja. Zdaniem Mohammada Reza Kamali największą barierą w rozwoju współpracy gospodarczej na skalę oczekiwaną przez obie strony był brak odpowiednich warunków do inwestycji w postaci bazy prawnej i systemu kredytowego ${ }^{28}$. Co prawda w latach 2009-2010 powstały na Białorusi dwa banki z kapitałem niemal wyłącznie irańskim, lecz na tyle skromnym, że nie były one w stanie zaoferować jakichkolwiek kredytów o istotnym znaczeniu dla białoruskiej gospodarki ${ }^{29}$. Obsługiwały głównie irańskie inwestycje w Mińsku, takie jak centrum handlowe Magnit, luksusowy hotel, szpital czy centrum transportowo-logistyczne Przylesie ${ }^{30}$.

23 Беларусь и Иран планируют расширить сотрудничество в сфере АПК, [online] http://www. belta.by/ru/all_news/economics/Belarus-i-Iran-planirujut-rasshirit-sotrudnichestvo-v-sfere-APK_i_551390.html, 8 V 2015.

24 А.А. Шахбаз, Внешнеэкономическое и политическое.., s. 55.

25 Беларусь и Иран увеличивают товарооборот, 6 X 2010, [online] http://news.day.az/iran/232053. html, 8 V 2014.

26 Ю.В. Коваленя, Нормативно-правовая база..., s. 53; Беларусь и Иран считают возможныцм увеличить товарооборот в 10 раз до 1 млрд. долларов, 27 XI 2009, [online] http://bdg.by/news/ finance/10121.html, 8 V 2014.

27 Посольство Республикой Беларусь в Исламской Республике Иран. Торгово-экономические отношения, [online] http://iran.mfa.gov.by/ru/bilateral_relations/trade_economic/, 29 XII 2015; А. КАасковский, Аруг Махмудне...

28 М.К. Мохаммдреза, Инвестициии и экономика Ирана в Беларуси: оченки, перспективыь, „Новая экономика" 2013, vol. 2, nr 62, s. 83-89.

29 А.А. Шахбаз, Внешнеэкономическое и политическое взвимодействие..., s. 57.

30 Tamże, s. 58. 
Podczas spotkań białoruskich i irańskich delegacji rządowych oraz kół biznesowych z obu stron pojawiały się zapewnienia o zainteresowaniu rozwojem kontaktów, woli inwestowania na obszarze partnera, poszerzaniu współpracy politycznej i wojskowej. Prezentowano jedność poglądów i dążeń niemal we wszystkich sprawach dotyczących relacji gospodarczych między Białorusią i Iranem, lecz nie przekładało się to na realne wyniki w postaci wymiany towarów, usług i myśli technologicznej. Najczęściej jako obszary potencjalnej współpracy wskazywano energetykę, budownictwo, przemysł spożywczy oraz sferę usług informatycznych ${ }^{31}$.

Najwięcej emocji w świecie budziła białorusko-irańska współpraca wojskowa. W 2005 r. pojawiły się podejrzenia o możliwość sprzedaży przez Białoruś Iranowi, objętemu embargiem ONZ, systemu obrony powietrznej S-300 32. Wiadomość nie została potwierdzona przez żadne wiarygodne źródło. W 2009 r. informacje o S-300 ponownie stały się przedmiotem spekulacji polityków i publicystów ${ }^{33}$. Władze białoruskie zdecydowanie zaprzeczały, aby udostępniły Iranowi system zdolny do niszczenia celów ataku powietrznego ${ }^{34}$. O braku takich dostaw informował także najlepiej zorientowany $\mathrm{w}$ regionie wywiad izraelski ${ }^{35}$.

Jedyne potwierdzone i zrealizowane kontrakty w 2007 r. dotyczyły sprzedaży 37 czołgów T-72M1. Nie stanowily one jednak istotnego wzmocnienia potencjału militarnego Iranu. Prawdopodobne jest, że Białoruś za przyzwoleniem Rosji i poza formalnymi kanałami dostarczyła Iranowi po 2007 r. samoloty wojskowe, bojowe wozy piechoty oraz artylerię do obrony powietrznej ${ }^{36}$. Współpraca w tej dziedzinie możliwa była jednak tylko w granicach określonych przez Rosję, której niekiedy, ze względu na prestiż międzynarodowy, nie opłacało się sprzedawać broni bezpośrednio do kraju objętego sankcjami ONZ.

Dostawom uzbrojenia towarzyszyła pomoc doradcza białoruskich instruktorów, a od 2010 r. także wspólne prace nad tworzeniem systemów informatycznych dla potrzeb cywilnych i wojskowych. Impulsem do poszerzenia współpracy w tej dziedzinie było zahamowanie przez izraelski wywiad irańskiego programu atomowego przez wprowadzenie wirusa do sytemu obsługującego proces pozyskiwania paliwa jądrowego. Zostały wówczas zniszczone rezultaty dwóch lat pracy irańskich specjalistów. Białoruscy programiści mieli być wówczas zatrudnieni przy tworzeniu systemów zabezpieczających przed atakami z cyberprzestrzeni na strategicznie ważne obiekty Iranu. W zamian uczeni irańscy mieli uczestniczyć w budowie białoruskiej elektrowni

31 Экономический форум Беларуси и Ирана, „Бюлетень деловой и комерческой информации” 2012, vol. 2, nr 25.

32 В. Каміноўскі, Амәрыканскія экспэрты: Беларусь можа прадащь Ірану ракеты C-300, 14 IV 2006, [online] http://www.ciwr.org/article/2006/04/14_s-300_print.html, 2 VI 2016.

33 С. Богдан, От Каракаса до Тегерана..., s. 113.

34 Азяржаўны ваенна-прамысловы камітэт: Беларусь не прадавала Iрану C-300, [online] http://old. euroradio.fm/by/1296/news/51139/, 6 V 2015.

35 Іран не купляу ракетныя комплексы С-300 у Беларусі, 30 IV 2014, [online] http://www.nv-online. info/by/97/20/18716/, 6 V 2015.

36 B. Bojarczyk, Stosunki biatorusko-irańskie, s. 259. 
atomowej ${ }^{37}$. Ten rodzaj współpracy świadczył o bardzo wysokim stopniu wzajemnego zaufania w relacjach białorusko-irańskich. Na płynące z różnych stron oskarżenia względem Białorusi o wspieranie polityczne i militarne obłożonego sankcjami Iranu do 2015 r. prezydent Łukaszenko odpowiadał: biatorusko-irańskie kontakty maja wytacznie pokojowy charakter i nie sa skierowane przeciwko jakimkolwiek państwom lub sojuszom ${ }^{38}$.

Niechęć do globalizacji i Stanów Zjednoczonych - głównego rzecznika nowego porządku światowego - łączyła przywódców Białorusi i Iranu z prezydentem Wenezueli Hugo Chávezem, który odwiedzał Teheran równie często, jak Mińsk. Reprezentowali oni kraje, które współpracowały politycznie i wspierały się na arenie międzynarodowej, lecz ze względu na oddalenie geograficzne i skromne potencjały ekonomiczne nie były w stanie stworzyć zwartego bloku realnie wpływającego na kształt stosunków międzynarodowych. Władze Białorusi, Iranu i Wenezueli przejawiały ogromną determinację, wzajemnie wspierając się w rozwiązywaniu problemów gospodarczych wynikających $\mathrm{w}$ dużej mierze z sankcji nakładanych przez państwa Zachodu. W przypadku Białorusi ani irańska, ani wenezuelska ropa nie mogła zastąpić dostaw tego surowca z Rosji i tym samym obniżyć rangi stosunków ze wschodnim sąsiadem.

\section{STOSUNKI Z IRAKIEM}

W Azji naturalnym sojusznikiem Białorusi do 2003 r. był także Irak, krytykowany przez Amerykanów za prześladowania Kurdów i mniejszości religijnych oraz za domniemane plany budowy bomby atomowej. Od czasu pierwszej wojny ze Stanami Zjednoczonymi w latach 1990-1991 Irak funkcjonował w cieniu sankcji ekonomicznych nałożonych przez ONZ. Był jednym z krajów „osi zła”, na której Amerykanie umieścili także Iran i Koreę Północną. Polityka takiego piętnowania państw była wielokrotnie potępiana przez prezydenta Eukaszenkę.

Stosunki dyplomatyczne Białorusi z Irakiem zostały nawiązane 9 lipca 1996 r. $^{39}$ Kraj ten wzbudzał zainteresowanie w Mińsku, podobnie jak Iran, nie tylko ze względu na kontekst polityczny, lecz przede wszystkim jako potencjalny odbiorca wyrobów białoruskiego przemysłu ciężkiego oraz dostawca ropy naftowej. Obroty handlowe Białorusi i Iraku, które w połowie lat 90. wynosiły około 100 tys. dolarów, u schyłku dekady osiągnęly wartość $38 \mathrm{mln}$ dolarów ${ }^{40}$. Było to wprawdzie niewiele w skali ogól-

37 А.А. Шахбаз, Внешнеэкономическое и политическое взвимодействие..., s. 58.

38 А. Аукашенко, Белорусско-иранские отношения не направлены против отдельньх стран или блоков - Аукашенко, 16 IV 2013, [online] http://www.interfax.by/news/belarus/1128629, $15 \mathrm{~V}$ 2016.

39 Указ Прэзідэнта Рэспублікі Беларусь 9 ліпеня 1996 г. N 251 2. Мінск аб устанаўленні дыцламатьцныьх адносін паміж Рэспублікай Беларусь і Рэспублікай Iрак, 9 XII 1996 [online] http://busel.org/texts/cat4xw/id5twbfeh.htm, 21 XII 2015.

40 Ирак и Иран - приоритеты белорусской внешней политики, 5 X 2002, [online] http://news.tut. by/society/18505.html, 21 XII 2015. 
nego wymiaru handlu zagranicznego obu krajów, lecz tendencje rozwojowe były bardzo wyraźne. W lipcu 1999 r. podpisano w Bagdadzie Porozumienie między rządem Republiki Biatorusi i rzadem Iraku o wspótpracy handlowej i ekonomicznej. Przewidywany zakres współpracy był bardzo szeroki i obejmował takie sektory, jak przemysł i energetyka, przetwórstwo naftowe, rolnictwo, transport i komunikacja, budownictwo, ochrona zdrowia, staże naukowe, wymiana specjalistów i doświadczeń, edukacja i badania naukowe ${ }^{41}$. Realizacją tego porozumienia miała zajmować się Białorusko-Iracka Komisja do spraw Współpracy Handlowo-Ekonomicznej, stanowiąca stały organ koordynujący działania podmiotów gospodarczych i naukowych obu państw. W wyniku pracy Komisji wartość podpisanych kontraktów w 2001 r. zbliżała się do $100 \mathrm{mln}$ dolarów. Pojawiły się perspektywy zachowania takiego tempa wzrostu także w następnych latach.

Furtką do zgodnej z prawem międzynarodowym współpracy z Irakiem był program ONZ Ropa w zamian za żywność. Operacje handlowe, które przynosiły pokaźne zyski, władze Białorusi przedstawiały jako pomoc humanitarną dla ludności Iraku dotkniętej sankcjami ONZ, wymuszonymi na większości państw członkowskich tej organizacji przez Amerykanów ${ }^{42}$. W ramach programu Ropa w zamian za żywność z Białorusi eksportowano do Iraku lekarstwa, sprzęt do budowy dróg, traktory, samochody ciężarowe oraz inwestowano w energetykę, przetwórstwo ropy naftowej i ochronę zdrowia ${ }^{43}$. Od lipca 1998 r. do ataku USA na Irak w 2003 r. strona białoruska dostarczyła na iracki rynek 2 tys. traktorów, 1,5 tys. autobusów, 200 tys. opon i 100 tys. ton armatury budowlanej ${ }^{44}$. Większe dostawy przewidziane na 2003 r. nie zostały zrealizowane z powodu wojny.

Analitycy białoruscy obliczyli, że po podboju Iraku przez Amerykanów w 2003 r. Białoruś straciła $500 \mathrm{mln}$ dolarów ${ }^{45}$. Była to wartość kontraktów handlowych oraz środków zainwestowanych w tym kraju w ochronę zdrowia i różne sektory gospodarki.

Niezbyt jasna była kwestia białoruskiej pomocy wojskowej dla Iraku. Ponieważ sprzedaż broni do tego kraju była objęta całkowitym embargiem, z punktu widzenia prawa międzynarodowego wszelkie transakcje z nią związane były nielegalne. Upowszechniane przez polityków amerykańskich i brytyjskich sensacje dotyczące udziału Białorusi i Ukrainy w budowaniu arsenału atomowego Iraku były, jak się okazało, całkowicie bezpodstawnymi oskarżeniami, które prawdopodobnie miały doprowadzić do zmniejszenia aktywności obu postradzieckich krajów w rejonie Zatoki Perskiej.

41 Пагадненне паміжк урадам Рэспублікі Беларусь і урадам Рэспублікі Ірак аб ганлёвым і эканамічнымм супрачоунічитве, [w:] Знешняя палітыка Беларусі..., s. 329.

42 Аб візіңе беларускай дэлегащъіі ў Iрак, [online] http://www.mfa.gov.by/print/ru/press/news/2002-04-22-7.html, 21 XII 2015.

43 Аукашэнка - сябра Iрака, [online] http://news97.com/b/index.phtml?sid=0\&did=1\&eid=10\&a$\mathrm{id}=2002 \&$ nid $=22,21$ XII 2015.

44 Беларусь теряет от войны в Ираке до500 млн. упущенной выгодъ, „Белоруская деловая газета” 2003, 30 XII, [online] http://bdg.by/news/news.htm?41976, 21 XII 2015.

45 Tamże. 
Niewątpliwie służyły także budowaniu psychozy zagrożenia i stanowiły część przygotowań propagandowych usprawiedliwiających planowaną agresję na Irak ${ }^{46}$.

$\mathrm{Z}$ udostępnianych środkom masowego przekazu fragmentów sprawozdań CIA wynikało, że dostaw wysokich technologii wojskowych do Iraku dokonywano za zgodą Aleksandra Łukaszenki, co stanowiło naruszenie postanowień ONZ z 1995 r. o zakazie handlu bronią z tym krajem. Wsparcie białoruskie dotyczyło budowy systemów radarowych, wykorzystania broni laserowej oraz elektronicznych środków łączności, modernizacji będących w dyspozycji wojsk irackich radzieckich czołgów, śmigłowców i samolotów oraz systemów obrony przeciwlotniczej ${ }^{47}$. Większość operacji transportowych sprzętu wojskowego do Bagdadu miała być przeprowadzana pod szyldem misji humanitarnych. Nielegalnymi dostawami broni i technologii wojskowych - według tego źródła - miał zajmować się wspólny iracko-białoruski komitet, działający za zgodą najwyższych władz obu krajów. Na długiej liście osób zaangażowanych w nielegalny handel widniały nazwiska białoruskich ministrów, przemysłowców, naukowców, generałów i bankierów ${ }^{48}$.

W czasie wojny w 2003 r. zakazana broń, która miała być dostarczona z Białorusi do Iraku, nie została wykorzystana. Nie wiadomo zatem, czy została faktycznie przekazana. Białoruś, według propagandy zachodniej, miała przede wszystkim dostarczyć Irakowi system obrony przeciwlotniczej S-300. Całkowita bezradność armii irackiej wobec ataków amerykańskiego i brytyjskiego lotnictwa przemawia za tym, by informacje o białoruskiej pomocy wojskowej dla Iraku traktować głównie jako część propagandowych przygotowań do wojny.

W 2002 r. wartość białoruskiego eksportu do Iraku wyniosła 32,6 mln dolarów. W 2004 r., po inwazji amerykańskiej, eksport zmniejszył się do miliona dolarów, a w latach 2005-2007 skurczył się niemal do zera ${ }^{49}$. W 2011 r. dyplomacji białoruskiej udało się ponownie nawiązać kontakty gospodarcze z nowymi władzami w Bagdadzie i wyeksportować do tego kraju towary wartości $23 \mathrm{mln}$ dolarów, lecz chaos polityczny w Iraku i wojna z Państwem Islamskim przerwały proces powrotu na irackie rynki ${ }^{50}$.

46 We wrześniu 2002 r. amerykański tygodnik „The Observer”, powołując się na wiarygodne źródła rządów amerykańskiego i brytyjskiego, informował, że Saddam Husajn dysponował bronią jądrową i rakietami balistycznymi, a wśród zidentyfikowanych krajów, które dostarczyły mu potrzebne technologie, były Białoruś i Ukraina. Oba kraje dostarczać miały technologie nuklearne Irakowi od połowy lat 90. i zdaniem wojskowych ekspertów do spraw kontroli zbrojeń, w tym inspektorów ONZ, stanowiły ogromne niebezpieczeństwo dla pokoju światowego. Wiadomości te przedrukowywano i rozpowszechniano na stronach internetowych białoruskich organizacji pozarządowych: Беларусь nомогает Ираку создавать ядерное оружие (strona internetowa Хартыя'97), [online] http://news97.com/b/ index.phtml?sid=0\&did=23\&eid=09\&aid $=2002 \&$ nid $=21,21$ XII 2015.

47 Cуt. za: RFE/RL - Радыцё Свабода, Роля Беларусі у пастаўках вайсковага абсталяваньня й тэхналёгіяу у Ірак - выниятак з тэксту справаздачь ЦРУ, 26 X 2004, [online] http://www.svaboda.org/content/article/787949.html, 21 XII 2015.

48 Tamże.

49 С. Богдан, Om Каракаса до Тегерана..., s. 114.

50 А. Федоров, Беларусь вновь пытается наладить отношения с Ираком, „Новости tut.by” 2014, 2 IX, [online] http://news.tut.by/politics/413761.html, 16 V 2016. 
W latach 2009-2011 wraz postępującą stabilizacją sytuacji politycznej w Iraku zaczęła odradzać się współpraca gospodarcza z Białorusią, lecz daleko jej było do stanu z czasów Saddama Husajna, gdy wymiana handlowa stanowiła dopełnienie bardzo bliskich stosunków politycznych łączących reżimy w Mińsku i Bagdadzie.

W 2004 r. zawieszono prace ambasad obu krajów. Wznowienie działalności irackiej placówki dyplomatycznej w Mińsku nastąpiło w 2008 r., a białoruskiej w Bagdadzie - rok później. Pierwsza białoruska delegacja rządowa z ministrem spraw zagranicznych Władimirem Makiejem odwiedziła Irak w sierpniu 2014 r. ${ }^{51}$ Została przyjęta przez prezydenta Fu’ada Masuma i premiera Nuri al-Malikiego. W tym czasie władze w Bagdadzie kontrolowały niewielką część państwa, które przed inwazją USA i sojuszników stanowiło terytorium Iraku. Planowanie poważnych relacji międzypaństwowych w tych warunkach było całkowicie irracjonalne.

\section{STOSUNKI Z SYRIĄ}

Równolegle z tworzeniem fundamentów pod przyszłą współpracę z Iranem prezydent Łukaszenko podobne działania podejmował wobec Syrii. Oświadczenie wydane wraz z prezydentem Hafizem al-Asadem 11 marca 1998 r. było łudząco podobne w treści do dokumentu podpisanego kilka dni wcześniej z Mohammadem Khatami ${ }^{52}$. Aleksander Łukaszenko deklarował się jako zwolennik pokojowego rozwiązania konfliktu arabsko-żydowskiego, a jednym z warunków pokoju - jego zdaniem - powinno być oddanie Syrii okupowanych przez Izrael Wzgórz Golan. Oba kraje wypowiadały się przeciwko sankcjom nałożonym na Irak, za suwerennością i integralnością tego państwa zagrożoną przez potencjalną agresję ze strony USA ${ }^{53}$.

Podczas drugiej wizyty w Damaszku 11 grudnia 2003 r. Aleksander Łukaszenko oświadczył wprost: chcemy traktować wykorzystać Syrie jako terytorium, z którego będziemy rozwijać współpracę gospodarczą z całym światem arabskim, z całym Bliskim Wschodem ${ }^{54}$. Wcześniej rozważano, czy takiej roli nie mógłby pełnić Egipt, lecz jakość relacji politycznych z Syrią i zmiana sytuacji geopolitycznej w regionie po amerykańskim ataku na Irak wpłynęła na wybór Damaszku jako głównego ośrodka lokowania białoruskich interesów na Bliskim Wschodzie.

Antyamerykanizm przywódców, podobnie jak w przypadku Iranu i Iraku, sprzyjał zbliżeniu politycznemu Białorusi i Syrii. W pierwszej fazie kształtowania się stosunków między obu krajami rola czynnika gospodarczego była bardzo niewielka ${ }^{55}$. Obroty

51 Беларусь восстанавливает отношения с Ираком, 25 V 2018, [online] http://afn.by/news/i/198173, $16 \mathrm{~V} 2016$.

52 Сумесная беларуска-сірыйскал заява, [w:] Знешнял палітыка Беларусі..., s. 169-171.

53 Tamże, s. 170.

54 Т. Евсейчик, O некоторьхх аспектах ближневосточной политики Республики Беларусь, „Белорусский журнац международного права и международных отношений” 2004, nr 4, [online] http:// evolutio.info/content/view/717/55/, 12 V 2016.

55 Якія інтарэсы могущъ аб’ядноувващь Беларусь і Сірыю (wypowiedź Andrieja Fiodorowa), [online] http://www2.polskieradio.pl/zagranica/ua/news/artykul136658.html, 28 XII 2015. 
handlowe obu państw w 1999 r. wynosiły 2,1 mln dolarów. Syria służyła wówczas jako kraj tranzytowy dla białoruskich towarów dostarczanych do Iraku. Ze względu na geopolityczne położenie jej znaczenie dla polityki A. Łukaszenki było dość duże. Syryjski prezydent Hafiz al-Asad był politykiem mającym doświadczenie współpracy z ZSRR. Prezydent Łukaszenko, podkreślający swoje przywiązanie do radzieckich tradycji politycznych, był rozmówcą ideowo bliskim Asadowi, co podkreślał w swoich późniejszych wypowiedziach ${ }^{56}$.

Bliskie relacje białorusko-syryjskie zostały zachowane także po objęciu władzy przez Baszszara al-Asada. Prezydent Białorusi przy każdej okazji bardzo ciepło wyrażał się o nowym syryjskim przywódcy, deklarując nadzieję na poszerzanie współpracy obu krajów ${ }^{57}$. Aleksander Łukaszenko budował klimat sprzyjający otwieraniu syryjskiego rynku dla produktów białoruskiego przemysłu spożywczego, chemicznego i zbrojeniowego. Damaszek był miejscem częstych wizyt białoruskich delegacji parlamentarnych i specjalnych misji dyplomatycznych. Wyniki tych działań były widoczne już wkrótce. W 2008 r. wielkość wymiany handlowej wzrosła do 85,5 mln dolarów ${ }^{58}$. Ponad $80 \%$ tej wartości stanowił białoruski eksport. Znaczną jego część stanowiły dostawy dla syryjskiej armii. Białoruscy specjaliści modernizowali sprzęt wojskowy pochodzący jeszcze z czasów radzieckich. Ze względu na kryzys, który dotknął zarówno Syrię, jak i Białoruś w 2009 r. wartość obrotów zmniejszyła się do 57,7 mln dolarów, z tendencją do dalszego obniżania w następnych latach, tym razem z powodu nasilającego się konfliktu wewnętrznego w Syrii. W 2011 r. obroty wyniosły zaledwie 30,3 mln dolarów ${ }^{59}$. Załamania w handlu między obu krajami nie zdołały powstrzymać bardzo bliskie relacje polityczne łączące przywódców Syrii i Białorusi.

Podczas wizyty Baszszara al-Asada w Mińsku w lipcu 2010 r. podjęto próbę odwrócenia negatywnych tendencji w stosunkach handlowych. Prezydentowi towarzyszył zespół złożony ze 120 przedstawicieli syryjskiego biznesu i najwyższych urzędników państwowych. Podpisano wówczas kilkanaście umów dotyczących współpracy na wszystkich możliwych polach relacji międzypaństwowych. Najważniejsze dotyczyły budowy na terenie Syrii montowni białoruskich samochodów ciężarowych i autobusów z przeznaczeniem na eksport do sąsiednich państw Bliskiego Wschodu. Ponadto białoruscy geolodzy mieli brać udział w poszukiwaniach złóż gazu i ropy naftowej. W procesie wydobycia $i$ handlu surowcami energetycznymi oba kraje zamierzały współpracować

56 А. Аукашэнка, Беларусь $і$ Сірыл могущь значна рушьць наперад у палітыцнай $і$ гандлёва-эканамічнайсферах, [online] http://news.belta.by/by/main_news?id=561694,2 I2016; Аукашэнка прызиаусся ў любові да Сірыі і зноу лаяу Paсею, [online] http://75.125.122.107/be/news/2010/ 7/26/30850/, 28 XII 2015.

57 Белорусско-сирийские торгово-экономические отношения существенно растиряютося, 31 VIII 2007, [online] http://president.gov.by/ru/news_ru/view/belorussko-sirijskie-torgovo-ekonomicheskie-otnoshenija-suschestvenno-rasshirjajutsja-2708/, 12 V 2016.

58 С. Сидорский, Беларусь рассиитььвает на расширение торгово-экономического сотрудничества с Сирией, [online] http://www.government.by/ru/content/148/print, 12 V 2016.

59 А.П. Косов, Белорусско-сирийские отношения в конще XX - начале XXI вв., „Вестник Брестского государственного технического университета" 2013, nr 6, s. 20. 
z Wenezuelą. Białoruś optowała za budowaniem strefy wolnego handlu między Syrią i Euroazjatycką Unią Celną, którą tworzyła wraz z Rosją i Kazachstanem ${ }^{60}$.

Ważnym elementem w relacjach dwustronnych miała być współpraca w zakresie obronności. Podczas pobytu Baszszara al-Asada w Mińsku pokazywano mu przede wszystkim zakłady, których produkcja służyła zaopatrzeniu wojska ${ }^{61}$. Część krajów arabskich, w tym Syria, wcześniej otrzymywała uzbrojenie ze Związku Radzieckiego. Arsenały te wymagały modernizacji, a Białoruś dysponowała sporym potencjałem oddziedziczonym po Armii Czerwonej. Dlatego łatwo zajęła istniejącą niszę na rynku zbrojeniowym tego regionu ${ }^{62}$.

Stosunki polityczne obu krajów były zbudowane na bliskości poglądów rządzących elit $\mathrm{w}$ kwestii większości problemów międzynarodowych. Wypowiedzi prezydentów Łukaszenki i Asada na temat roli mocarstw we współczesnym świecie czy sytuacji w regionie Bliskiego Wschodu przedstawiały bardzo zbliżone poglądy. Obaj prezydenci akcentowali potrzebę odrzucenia polityki dyktatu w stosunkach międzynarodowych, zwłaszcza w kontekście roli obecności amerykańskiej w sąsiedztwie zarówno Syrii, jak i Białorusi ${ }^{63}$.

Arabska Wiosna, która dotarła do Syrii na początku 2011 r., oraz trwająca wojna domowa w Mińsku zostały zinterpretowane jako wynik zewnętrznego zaangażowania. Przedstawiciele Białorusi opowiadali się przeciwko mieszaniu się obcych państw w sprawy zaprzyjaźnionego kraju i za pokojowym uregulowaniem konfliktu wewnętrznego ${ }^{64}$. Wojna spowodowała wzrost zapotrzebowania na broń. Według syryjskiej opozycji Białoruś stała się drugim po Rosji dostawcą uzbrojenia dla armii Baszszara al-Asada, co dało podstawy do oskarżeń władz białoruskich o przyczynianie się do zwiększania liczby ofiar wśród ludności cywilnej ${ }^{65}$. Amerykanie nałożyli nawet w 2011 r. sankcje na białoruską firmę Biełwnieszpromserwis za współpracę z syryjskim Biurem Zaopatrzenia Wojskowego i dostarczenie zapalników do bomb lotniczych, które były zrzucane na Aleppo $^{66}$. MSZ Białorusi odrzuciło amerykańskie oskarżenia, a sankcje nazwało działaniami ukierunkowanymi na izolację międzynarodową Syrii i Białorusi.

Niezależni białoruscy obserwatorzy twierdzą, że dostawy białoruskiej broni dla armii Baszszara al-Asada zostały mocno ograniczone wraz z początkiem wojny domowej w tym kraju. Białoruskie firmy zajmujące się eksportem broni zostały wyrugowane z syryjskiego rynku przez rosyjski koncern Rosoboronexport ${ }^{67}$. Pozostali w Syrii białoruscy

60 Tamże.

61 Р. Яковлевский, Сирия проявляет особыци интерес к продукции МЗКТ, 17 VI 2012, [online] https://charter97.org/ru/news/2012/6/17/53877/, 13 V 2016.

62 С.Ф. Свилас, Т.В. Евсейчык, Отношения Республики Беларусь..., s. 28.

63 Беларусь и Сирия активизируют торгово-экономические отномения, [online] http://www.b-info. by/news/14713/, 14 V 2016.

64 А.П. Косов, Белорусско-сирийские отношения..., s. 19.

65 У. Мунажия, Сирийских детей убивают белоруским оружием, 1VI 2012, [online] https:// charter97.org/ru/news/2012/6/1/53166/, 13 V 2016.

66 А.П. Косов, Беморусско-сирийские отношения..., s. 19.

67 М. Виталь, Беларусь - Сирия: поперёд Батьки в пекло, 14 III 2016, [online] https://cont.ws/ post/223451, 14V 2016. 
specjaliści, którzy od dłuższego czasu zajmowali się remontem postradzieckiego sprzętu wojskowego (głównie samolotów i czołgów).

W 2014 r. białorusko-syryjska współpraca polityczna stała się bardziej złożona. Białoruś, która odegrała znaczącą rolę w zainicjowaniu procesu mediacyjnego w sprawie konfliktu na wschodzie Ukrainy, zyskała z tego powodu uznanie Unii Europejskiej, czego dalszą konsekwencją było stopniowe znoszenie sankcji nałożonych w 2011 r. Otwarta współpraca z Baszszarem al-Asadem, którego ustąpienia ze stanowiska domaga się m.in. Bruksela, mogłaby hamować proces normalizacji relacji Białorusi z Unią Europejską. Wielkość wymiany handlowej z krajami Unii jest obecnie prawie 60 razy większa niż wielkość wymiany handlowej z Syrią. Dlatego kontakty międzypaństwowe z Syrią, mimo niezmiennej przychylności dla reżimu w Damaszku, utrzymywane są za pośrednictwem polityków niekojarzonych bezpośrednio z prezydentem Łukaszenką.

W lutym 2016 r. na czele delegacji białoruskiej, której ranga jest trudna do ustalenia, stał pierwszy sekretarz Komunistycznej Partii Białorusi Igor Karpienka. Delegacja została przyjęta przez Baszszara al-Asada, zaś Karpienka publicznie wypowiadał się w imieniu państwa białoruskiego, chociaż nie sprawował żadnej funkcji państwowej ${ }^{68}$. Zapewne pełnił rolę zaufanego łącznika między Aleksandrem Łukaszenką a Baszszarem al-Asadem.

Prezydent Białorusi pytany latem 2013 r. o ocenę polityki syryjskiego prezydenta stwierdził, że to europejski cywilizowany cztowiek, który broni swojego kraju przed terrorystami zorganizowanymi i finansowanymi przez USA ${ }^{69}$. Próby obalenia Asada nazwat przestępstwem. Gdy relacje Białorusi z Zachodem zaczęły się normalizować, Łukaszenko unikat już tak jednoznacznych określeń. Nie oznacza to jednak zmiany polityki Mińska wobec Syrii czy rezygnacji z poparcia dla prezydenta Asada. W tym zakresie polityka Białorusi jest zbieżna z rosyjską, lecz skala bezpośredniego zaangażowania w konflikcie syryjskim, w porównaniu do obecności rosyjskiej, jest raczej symboliczna.

\section{BIBLIOGRAFIA:}

Aб візіңе беларускай дэлегащыьі ў Iрак, [online] http://www.mfa.gov.by/print/ru/press/ news/2002-04-22-7.html.

Беларусь восстанавливает отношения с Ираком, 25 V 2018, [online] http://afn.by/ news/i/198173.

Беларусь - Иран: многранность взаимодействия, [online] http://www.export.by/?act= news\&mode $=$ view\&id $=23759$.

Беларусь и Иран планируют растирить сотрудничество в сфере АПК, [online] http://www. belta.by/ru/all_news/economics/Belarus-i-Iran-planirujut-rasshirit-sotrudnichestvo-v-sfere-APK_i_551390.html.

\footnotetext{
68 Tamże.

69 Tamíe.
} 
Беларусь и Иран считают возможньм увеличить товарооборот в 10 раз до 1 млрд. доларов, 27 XI 2009, [online] http://bdg.by/news/finance/10121.html.

Беларусь и Иран увеличивают товарооборот, 6 X 2010, [online] http://news.day.az/ iran/232053.html.

Беларусь-Иран: совместнье проекть на сумму \$1,5 млрд. или 1000 и одна сказка, 12 II 2009 , [online] http://afn.by/news/i/113669.

Беларусь и Сирия активизируют торгово-экономические отношения, [online] http:// www.b-info.by/news/14713/.

Беларусь помогает Ираку создавать ядерное оружие, (strona internetowa Хартыя'97), [online] http://news97.com/b/index.phtml?sid=0\&did=23\&eid=09\&aid=2002\&nid=21.

Беларусь теряет от войны в Ираке до500 млн. упущенной выцодьь, „Белоруская деловая газета" 2003, 30 XII, [online] http://bdg.by/news/news.htm?41976.

Белорусско-сирийские торгово-экономические отношения существенно растиряются, 31 VIII 2007, [online] http://president.gov.by/ru/news_ru/view/belorussko-sirijskie-torgovo-ekonomicheskie-otnoshenija-suschestvenno-rasshirjajutsja-2708/.

С. Богдан, Om Каракаса до Тегерана: белорускал дипломатия в Азии, Аатинской Америке и Африке, „Бемоуский ежегодник” 2009.

Bojarczyk B., Stosunki biatorusko-irańskie, [w:] Biatoruś w stosunkach międzynarodowych, red. I. Topolski, Lublin 2009.

Виталь М., Беларусь - Сирия: поперёд Батьки в пекло, 14 III 2016, [online] https://cont.ws/ post $/ 223451$.

Азяржауны ваенна-прамысловы камітэт: Беларусь не прадавала Ірану C-300, [online] http://old.euroradio.fm/by/1296/news/51139/.

Евсейчик Т., О некоторьх аспектах ближневосточной политики Республики Беларусь, „Беморусский журнац международного права и международных отношений” 2004, nr 4, [online] http://evolutio.info/content/view/717/55/.

Иванов К., Как Беларусь собиралась торговать с Ираном на \$ 1 млрд и ито из этого въцило, „Сацідарнасць” 2015, 17 II, [online] http://www.gazetaby.com/cont/print_rdn. php?sn_nid $=90355$.

Ирак и Иран - приоритеты белорусской внешней политики, 5 X 2002, [online] http://news. tut.by/society/18505.html.

Іран не купляу ракетныля комплексы С-300 у Беларусі, 30 IV 2014, [online] http://www.nv-online.info/by/97/20/18716/.

Іран рэалізуе ў Беларусі праекты на 1,5 млрд. даляраў, [online] http://telegraf.by/2011/02/ ran-realzue-belarus-praekti-na-15-mlrd-daljara.html.

Каміноўскі В., Амэрыканскія экспэрты: Беларусь можа прадащь Ірану ракеты С-300, 14 IV 2006, [online] http://www.ciwr.org/article/2006/04/14_s-300_print.html.

Кітай надасиь Беларусі крэдьт на адзін мільярд далsраў, [online] http://telegraf. by/2010/03/ktaj-nadasc--belarus-kredit-na-adzn-ml-jard-daljara.html.

КАасковский А., Аруг Махмудне оправдал надежд Аукашенко, „Самідарнасць” 2013, 11 II, [online] http://www.gazetaby.com/cont/art.php?sn_nid=53634.

Коваленя Ю.В., Нормативно-правовал база взаимодействия Беларуси и Ирана (1993-2014), [w:] Белорусь в современном мире. Материаль IX Международной научной 
конферэнщии посвященной 93-летию образования Белорусского государственного университета, Минск 2014.

Коровенкова Т., Беларусь и Иран полностью закрыли проект по добыче нефти на Ажофеире, „Самідарнасць” 2013, 5 II, [online] http://www.gazetaby.com/cont/art. php?sn_nid=53423.

Косов А.П., Белорусско-сирийские отношения в конце XX-начале XXI вв., „Вестник Брестского государственного технического университета" 2013, nr 6.

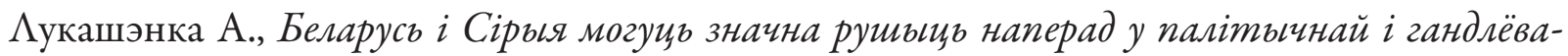
-эканамічнай сферах, [online] http://news.belta.by/by/main_news?id=561694.

Аукашэнка: незалежнасиь ад расійскай нафты і газу каштуе вельмі дорага, [online] httр:// telegraf.by/2010/09/lukashenka-nezalezhnasc--ad-rasjskaj-nafti-gazu-kashtue-vel-m-doraga.html.

Аукашэнка прызнауся ў любові да Сірыі і зноў лаяў Расею, [online] http://75.125.122.107/ be/news/2010/7/26/30850/.

Аукашэнка - сябра Iрака, [online] http://news97.com/b/index.phtml?sid=0\&did=1\&eid= 10\&aid=2002\&nid $=22$.

Аукашенко А., Белорусско-иранские отношения не направлень против отдельньх стран или блоков - Аукашенко, 16 IV 2013, [online] http://www.interfax.by/news/ belarus/1128629.

Аукоянов А., Иран: взгляд без предубеждения, [online] http://polit.ru/research/2008/03/16/ iran.html.

Мацель В., Отношения Республики Беларусь с государствами северо-восточной Азии, [online] http://www.library.by/portalus/modules/belarus/referat_readme.php?subaction=sho wfull \&id $=1182261885 \&$ archive $=\&$ start $\_$from $=\& u c a t=4 \&$.

Mironowicz E., Polityka zagraniczna Biatorusi 1990-2010, Białystok 2011.

Мохаммдреза М.К., Инвестиииии и экономика Ирана в Беларуси: оченки, перспективь, „Новая экономика” 2013, vol. 2, nr 62.

Мунажия У., Сирийских Сирийских детей убивают белорусским оружием, 1VI 2012, [online] https://charter97.org/ru/news/2012/6/1/53166/.

Паведамленне МЗС Рэспублікі Беларусь аб візіче у Беларусь прэзідэнта Ірана, „Веснік Міністэрства замежных спрау” 2007, nr 2.

Пагадненне паміж урадам Рэспублікі Беларусь і уррадам Рэспублікі Ірак аб ганлёвым і эканамічным супрацоўніцтве, [w:] Знешнял палітькка Беларусі. Зборнік дакументау i матэрыялаў (1996-2000), t. 8, Мінск 2008.

Роля Беларусі ў пастаўках вайсковага абсталяваньня й тэхналёгілў у Ірак - вьнятак з тэксту справаздачы ЦРУ, 26 X 2004, [online] http://www.svaboda.org/content/article/787949.html.

Торгово-экономические отношения, Посольство Республикой Беларусь в Исламской РеспубликеИран, [online] http://iran.mfa.gov.by/ru/bilateral_relations/trade_economic/.

Свикас С.Ф, Евсейчык Т.В., Отношения Республики Белорусь со странами Арабского мира в 1996-2006 годах, Минск 2009.

Сидорский С., Беларусь рассчитыьвает на растирение торгово-экономического сотрудниества с Сирией, [online] http://www.government.by/ru/content/148/print. 
Сумесная беларуска-іранская залва, [w:] Знемняя палітыка Беларусі. Зборнік дакументаў і матэрыслиаў (1996-2000), t. 8, Мінск 2008.

Указ Прэзідэнта Рэспублікі Беларусь 9 ліпеня 1996 г. N 251 г. Мінск аб устанаўленні дыпламатычных адносін паміж Рэспублікай Беларусь і Рэспублікай Iрак, 9 XII 1996 [online] http://busel.org/texts/cat4xw/id5twbfeh.html.

Федоров А., Беларусь вновь пытается наладить отношения с Ираком, „Новости tut.by” 2014, 2 IX, [online] http://news.tut.by/politics/413761.html.

Шахбаз Асгар А., Внешнеэкономическое и политическое взаимодействие Республики Беларусь и Республики Иран в условиях глобализации, „Иппокрена” 2015, vol. 1, nr 26.

Экономический форум Беларуси и Ирана, „Бюлетень деловой и комерческой информации” 2012, vol. 2, nr 25.

Чаму Беларусь і Іран иягнуциа адзін да аднаго?, оріпіе Igora Lalkowa i Andreja Fiodorowa, [online] http://news.akavita.by/ru/belarus/248190.html.

Якія інтарэсы могуць аб’ядноуващъ Беларусь і Сірыюо (wypowiedź Andrieja Fiodorowa), [online] http://www2.polskieradio.pl/zagranica/ua/news/artykul136658.html.

Яковлевский Р., Сирия проявляет особъй интерес к продукщии МЗКТ, 17 VI 2012, [online] https://charter97.org/ru/news/2012/6/17/53877/.

Eugeniusz MIRONOWICZ - prof. dr hab., kierownik Katedry Polityki Międzynarodowej Instytutu Historii i Nauk Politycznych Uniwersytetu w Białymstoku. Zainteresowania badawcze: polityka zagraniczna państw postradzieckich, problemy narodowościowe w Europie Wschodniej, najnowsza historia Białorusi. Autor książek: Biatorusini i Ukraińcy w polityce obozu pitsudczykowskiego (Białystok 2007), Historia państw świata XX wieku. Biatorus' (Warszawa 1999 i 2007), Polityka zagraniczna Biatorusi 1990-2010 (Białystok 2011), Polityka zagraniczna Ukrainy 1990-2010 (Białystok 2012); Wojna wszystkich ze wszystkimi. Biatoruś 1941-1944 (Kraków 2015). 